\title{
Role of Panchayat Raj Institutions in Rural Electrification in Karnataka -With Special Reference to Mysore District
}

\author{
${ }^{1}$ Sandeep Raj.K and ${ }^{2}$ Dr.V.Shanmugam \\ ${ }^{1}$ (Research Scholar, DOS in Economics \& Co-operation, Manasagangothri, Mysore, Karnataka State, India.) \\ ${ }^{2}$ (Associate Professor of Economics, Maharaja's College, University of Mysore, Mysore Karnataka State, India)
}

\begin{abstract}
Local Government which is named as Panchayat Raj Institutions plays a major role in the economic development of any region in India. In the pre-independence period these institutions were not systematically arranged and they were handled by the elders of the region or villages. Now a day these institutions are systematically arranged and constitutional provisions are made to strengthen the PRIs to engage in the development of any region. Relating to the socio-economic development of a region PRIs have its own 29 subjects which is provisioned under the Constitution of India, in that rural electrification is also one of the important issues deputed to PRIs. This paper discusses about, how rural area are electrified in Karnataka state and its status as well as in the study region and this study exhibits its own findings.
\end{abstract}

\section{Introduction}

Economic development is a process of creating institutions to promote standard of living of people in any region. Economic development involves decision making process. In a democratic governing system people's participation is essential for their economic development. Democratic political institutions are being created to take decisions regarding the economic development of people in any region. In India local self governments named as Panchayat Raj institutions play a major role in economic development of rural India.

The people in rural India elect their representatives to the village Panchayats, Thaluk Panchayats and Zilla Panchayats. These rural political institutions take decisions regarding the economic requirements on behalf of their voters. These institutions promote agriculture, small-scale industries and rural services such as housing, education, health, transport, drinking water, power, preservation of local environment etc. Thus these rural political institutions are established in India to take care of the economic development process in rural India.

The basic concept of Panchayat Raj is that the villagers should think, decide and act for their own socio-economic interests. The Panchayat Raj Act is related to village self governance, where the people in the form of an organization will think, decide and act for their collective interests, where the Panchayats ends their activities but the state governments push them forward. The state governments play their major role from the following points.

* To support the Panchayat Raj Institutions.

- To co-ordinate the Panchayat Raj Institutions.

* To ensure the implementation of this system for the development of people.

\section{Rural Electrification}

It is the method of bringing electrical power to rural and remote areas. Energy can be used not merely for lighting and household applications, but it additionally allows for mechanization of many farming operations, such as for example threshing, milking, and hoisting feed for storage. In places facing labor shortages, this allows for larger production at decreased cost. One popular plan was the New Package's Rural Electrification Government in the United Claims, which pioneered lots of the schemes however practiced in other countries. Based on IEA (2009) worldwide 1.456 million people (18\% of the world's population) do not need use of energy that $83 \%$ are now living in rural areas. In 1990 around $40 \%$ (2.2 billion) of the world's people however lacked power. Significantly of the increase in the last quarter century has been in India, facilitated by mass migration in powered urban areas. India was just $43 \%$ electrified in 1990 rather than about $75 \%$ in 2012. In $197937 \%$ of China's rural population lacked use of energy entirely. Some $23 \%$ of people in East Java, Indonesia, a key region, also lack energy, as surveyed in 2013.

\section{Objectives}

1. To study status of Rural Electrification in India.

2. To Study the status of Rural Electrification in Karnataka.

3. To examine the Rural Electrification in Mysore District. 


\section{Methodology}

On the basis of the above mentioned objectives, the following methodology will be adopted in this article. This has been analyzed under various sub headings as follows.

\section{Data Sources}

This study is purely based on the secondary data. The secondary data is collected from the published articles, books, documents, theses, periodicals, newspapers, internet sources. The data is also gathered from the Karnataka at a Glance 2013-14 and Mysore District at a Glance 2013-14. This secondary data is related to the Mysore district of Karnataka state has been selected for the study area. It is one of the pioneer districts in evolving the local government in Karnataka and relating to the implementation of the rural electrification programmes and in creating rural infrastructure.

\section{Rural Electrification In India}

Rural places in India are electrified non-uniformly, with thicker claims to be able to give most the villages with energy while worse claims however struggling to complete so. The Rural Electrification Organization Confined was shaped to particularly address the matter of giving energy in all the villages across the country. Poverty, lack of sources, lack of political will, poor preparing and energy robbery are some of the significant causes which has remaining many villages in India without energy, while cities have liked development in energy consumption and capacity. The central government is increasingly seeking to boost the horrible situations by trading seriously in bio-gas, solar as well as breeze energy. Programmes such as for example The JNN solar objective, Pradhan Mantri Gram Vidyut yojna to secure the speed of electrification and diversify the procedure. The task is also on-going for lowering wastage, giving better gadgets and increasing the overall infrastructure for electrical signals in villages. Currently, some $60 \%$ of villages in India have now been electrified with another purpose of giving total electrification by 2025. Upper and North-Eastern claims in India are lagging behind the national normal taking the numbers down, mostly due to inefficient state governments and lack of financial sources; these claims are now the target of many NGOs as well as state programs. It is projected that 1-2 GW of solar power will be required for the 1 lakh un-electrified villages in the United Kingdom, as well as the solar power requirements of un-electrified homes of electrified villages.

\section{Status Of Rural Electrification In Karnataka}

Karnataka is one of the pioneer states in India. According to 2001 census, 29406 total villages including 27482 inhabited and 1924 un-inhabited village and 270 urban areas. (KAG 2013)

Table No.1-Electrified Villages, Hamlets \& Ip Sets In Karnataka - 2012-13

\begin{tabular}{|c|c|c|c|c|}
\hline \multirow[b]{2}{*}{ Sl. No. } & \multirow[b]{2}{*}{ Districts } & \multicolumn{3}{|c|}{ Electrified upto 31.03.2013 } \\
\hline & & Villages & Hamlets & I.P.Stes \\
\hline 1 & Bangalore & 228 & 0 & 27365 \\
\hline 2 & Bangalore Rural & 1238 & 0 & 81058 \\
\hline 3 & Ramanagar & 1345 & 0 & 46950 \\
\hline 4 & Chitradurga & 1094 & 251 & 91678 \\
\hline 5 & Davangere & 946 & 140 & 90401 \\
\hline 6 & Kolar & 1732 & 136 & 73169 \\
\hline 7 & Chikkaballapur & 1451 & 126 & 72262 \\
\hline 8 & Shimoga & 1440 & 2190 & 55415 \\
\hline 9 & Thumkur & 2708 & 3514 & 199906 \\
\hline 10 & Chikkamagalore & 1033 & 3022 & 47229 \\
\hline 11 & Dhakshina Kannada & 356 & 3186 & 81072 \\
\hline 12 & Udupi & 254 & 3607 & 57749 \\
\hline 13 & Hassan & 2394 & 1415 & 76179 \\
\hline 14 & Kodagu & 296 & 610 & 7552 \\
\hline 15 & Mandya & 1369 & 623 & 73135 \\
\hline 16 & Mysore & 1216 & 516 & 60820 \\
\hline 17 & Chamarajanagar & 424 & 469 & 49780 \\
\hline 18 & Belagaum & 1254 & 564 & 235871 \\
\hline 19 & Bijapur & 665 & 858 & 103249 \\
\hline 20 & Bagalkote & 604 & 538 & 89256 \\
\hline 21 & Dharwad & 388 & 388 & 18854 \\
\hline 22 & Gadag & 321 & 164 & 22503 \\
\hline 23 & Haveri & 690 & 168 & 52779 \\
\hline 24 & Uttar Kannada & 1232 & 604 & 50748 \\
\hline 25 & Bellary & 537 & 0 & 43154 \\
\hline 26 & Bidhar & 613 & 0 & 56392 \\
\hline 27 & Gulbarga & 844 & 0 & 43154 \\
\hline
\end{tabular}




\begin{tabular}{|l|l|c|c|c|}
\hline 28 & Yadagiri & 500 & 0 & 20578 \\
\hline 29 & Raichur & 814 & 0 & 43063 \\
\hline 30 & Koppal Total & 624 & 0 & 49109 \\
\hline \multicolumn{2}{|c|}{ T8610 } & $\mathbf{2 3 0 8 9}$ & $\mathbf{2 0 2 0 4 3 0}$ \\
\hline
\end{tabular}

Source: Karnataka at A Glance-2013

The above table shows the electrified status of rural Karnataka, it shows 28,610 villages, 23,089 hamlets and 20,20,430 I.P.Sets are electrified in the State.

Table No.2- Non Electrified Villages, Hamlets \& Ip Sets In Karnataka - 2012-13

\begin{tabular}{|c|c|c|c|c|}
\hline \multirow[b]{2}{*}{ Sl. No. } & \multirow[b]{2}{*}{ Districts } & \multicolumn{3}{|c|}{ Non Electrified upto 31.03.2013 } \\
\hline & & Villages & Hamlets & I.P.Stes \\
\hline 1 & Bangalore & 0 & 0 & 0 \\
\hline 2 & Bangalore Rural & 0 & 0 & 0 \\
\hline 3 & Ramanagar & 0 & 0 & 0 \\
\hline 4 & Chitradurga & 0 & 0 & 0 \\
\hline 5 & Davangere & 0 & 0 & 0 \\
\hline 6 & Kolar & 0 & 0 & 0 \\
\hline 7 & Chikkaballapur & 0 & 0 & 3686 \\
\hline 8 & Shimoga & 3 & 17 & 2656 \\
\hline 9 & Thumkur & 0 & 9 & 15952 \\
\hline 10 & Chikkamagalore & 0 & 42 & 1584 \\
\hline 11 & Dhakshina Kannada & 0 & 1999 & 897 \\
\hline 12 & Udupi & 0 & 186 & 792 \\
\hline 13 & Hassan & 0 & 0 & 11983 \\
\hline 14 & Kodagu & 0 & 0 & 378 \\
\hline 15 & Mandya & 0 & 0 & 10805 \\
\hline 16 & Mysore & 0 & 0 & 6183 \\
\hline 17 & Chamarajanagar & 0 & 0 & 4648 \\
\hline 18 & Belagaum & 0 & 0 & 381 \\
\hline 19 & Bijapur & 0 & 0 & 107 \\
\hline 20 & Bagalkote & 0 & 0 & 2980 \\
\hline 21 & Dharwad & 0 & 0 & 1071 \\
\hline 22 & Gadag & 0 & 0 & 1013 \\
\hline 23 & Haveri & 0 & 0 & 1149 \\
\hline 24 & Uttar Kannada & 27 & 115 & 1222 \\
\hline 25 & Bellary & 0 & 0 & 1766 \\
\hline 26 & Bidhar & 0 & 0 & 577 \\
\hline 27 & Gulbarga & 0 & 0 & 1766 \\
\hline 28 & Yadagiri & 0 & 0 & 1269 \\
\hline 29 & Raichur & 0 & 0 & 985 \\
\hline 30 & Koppal & 0 & 0 & 846 \\
\hline & Total & 30 & 2368 & 74696 \\
\hline
\end{tabular}

Source: Karnataka at A Glance-2013

The above table shows the non-electrified status of rural Karnataka, it shows 30 villages, 2,368 hamlets and 74,696 I.P.Sets are non-electrified in the State. But the thing which the study is identified is in the above table of non-electrified status in Karnataka, in Mysore district it shows 6,183 I.P.Sets are not electrified, but in the below table which shows the electrified \& non-electrified status of Mysore District there not even single I.P.Sets is under the section of Non-electrified.

\section{Details Of Electrified And Non Electrified Villages, Hamlets \&} I.P.Sets In Mysore District

\begin{tabular}{|c|c|c|c|c|c|c|c|}
\hline \multicolumn{8}{|c|}{ No. of Electrified and Non Electrified Villages } \\
\hline Sl. & \multirow[b]{2}{*}{ Thaluks } & \multicolumn{3}{|c|}{ Electrified } & \multicolumn{3}{|c|}{ Non Electrified } \\
\hline no & & Villages & Hamlets & I.P.Sets & Villages & Hamlets & I.P.Sets \\
\hline 1 & H.D.Kote & 243 & 227 & 7932 & 0 & 0 & 0 \\
\hline 2 & Hunsur & 192 & 146 & 10910 & 0 & 0 & 0 \\
\hline 3 & K.R.Nagar & 156 & 80 & 4145 & 0 & 0 & 0 \\
\hline 4 & Mysore & 131 & 85 & 9728 & 0 & 0 & 0 \\
\hline 5 & Nanjangud & 176 & 99 & 12722 & 0 & 0 & 0 \\
\hline 6 & Periyapatna & 197 & 161 & 8538 & 0 & 0 & 0 \\
\hline 7 & T.Narasipura & 121 & 92 & 9234 & 0 & 0 & 0 \\
\hline \multicolumn{2}{|c|}{ District Total } & 1216 & 890 & 63209 & 0 & 0 & 0 \\
\hline
\end{tabular}

Source: Mysore District at a Glance 2013-14 
As the above tables shows the electrified and non-electrified villages, hamlets and I.P.Sets in Mysore District, there are 1,216 villages is electrified, 890 of hamlets and 63,209 I.P.Sets are electrified and it reveals that there is not even single village, hamlet and I.P.Sets is left with the non-electrified section and the efficient administration has done by the local bodies with concern to the rural electrification.

\section{Reference}

[1]. Prathap Ranjanaa Jena (2008), "Revenue Efforts of Panchayats: Evidence from Four States", Economic and Political Weekly, July 26, 2008, Vol. 43 (30-38).

[2]. Agnihotri.V.K (2002), "Socio-economic Profile of Rural India", concept publishing company, New Delhi, 2002 , pp.226.

[3]. Kulkarni.P.R (2000), "Financial Structure for Backward Area Development", Productivity, Vol. 41, No. 3, Oct- Dec, 2000.

[4]. Directorate of Economic and Statistics (2013-14), "Karnataka at a Glance", Government of Karnataka, Bangaluru.

[5]. Directorate of Economic and Statistics (2013-14), "Mysore District Statistics at a Glance", Government of Karnataka, Mysore.

[6]. Report of the Task Force on "Panchayati Raj Institutions (PRIs)", (2001), Planning Commission, New Delhi. 